\title{
The Effect of Employee's Working Satisfaction on Organization Commitment at PT (Persero) Angkasa Pura I Branch of Hasanuddin International Airport in Makassar
}

\author{
Indira Basalamah \\ Moeslim Indonesian University, Indonesia \\ Indira_Basalamah@yahoo.co.id
}

\begin{abstract}
The aim of the study was to dicover employee's working satisfaction and organization commitment and correlation and effect of working satisfaction factors such as compensation, job, immediate superior, promotion, and working partner on organization commitment. The study was conducted at PT (Persero) Angkasa Pura I Branch of Hasanuddin International Airport in Makassar. The study was descriptive. The data were collected through questionnaire. The number of samples was 65 employees as respondents selected by cluster sampling at 3 divisions. The independent variable of the study was working satisfaction (X) comprising compensation, job, supervisor, promotion, and working partner and the dependent variable is organization commitment ( $\mathrm{Y}$ ). The analysis used in the study was regression analysis. The result of the study indicate that the level of employee's working satisfaction and organization commitment are high. There is a strong correlation between working satisfaction and organization commitment at on commitment and working motivation also has a significant effect compensation, promotion, and working partner, but it has no significant effect on job and immediate superior.
\end{abstract}

Keywords: Working satisfaction, compensation, job, immediate superior, promotion, working partner, organization commitment

\section{Introduction}

Robert L. Khan expressing one's attitudes and job satisfaction within the organization is a major part of the individual 's behavior. Job satisfaction is an attitude of individuals in connection with their work. A study of attitudes towards work ( Job Attitudes ) of 6000 the industrial workers at a tractor factory in the United States shows that there are four relatively independent factors which contribute towards the formation of satisfaction achieved from a situation of total employment. The factors are: a) Intrinsic satisfaction of a job, b) Satisfaction with the company concerned, c) Satisfaction with supervision, d) Satisfaction with remuneration derived, e) Opportunities for mobility. The indicator can be used as a source of satisfaction for specific groups of workers, but for another group it became a source of dissatisfaction. According Handoko (2001) job satisfaction is an emotional state that is pleasant or unpleasant by which employees view their work. PT (Persero) Angkasa Pura I in improving employee satisfaction also experienced constraints. This is shown by the problems that occur in PT (Persero) Angkasa Pura I. Employees PAP-I collected in the union to strike PAP-I requires management to improve the welfare and the abolition of the criminalization of trade union the right to vote. Some things they demanded among other things an increase in basic salary, annuity, health, and pensions. The reason they do this action because until now there is no base salary adjustments still equivalent basic salary of civil servants in 2006. ( Source : Daily Fajar , Thursday, May 8, 2008 ).

The impact of job dissatisfaction is feared may reduce commitment to the organization. To create employees who are committed to the company, the company should consider factors - factors that influence commitment. Sopiah (2008) Suggested that there are eight factors that positively influence the organizational commitment, namely: 1. Promotion, 2. Characteristics of employment, 3. Communications, 4. Leadership, 5. The exchange of extrinsic, 6. Exchange of intrins, 7. Extrinsic rewards, 8. the intrinsic rewards. In addition, research conducted by Joseph et al. (2007) stated that job satisfaction has a direct relationship with organizational commitment. Most of the employees are satisfied with the company will have a strong commitment to the organization. Other studies conducted by Danan (2008) showed a positive and significant correlation relationship with job satisfaction and commitment organizational citizenship behavior. Individual attitude is the underlying basis for understanding exactly how employee commitment to the organization PAP-I in order to remain embodies the achievement of company goals, vision and mission of the company, 
which is based on the values of the corporate culture, the middle of dealing with problems of employee dissatisfaction PAP-I against compensation. This phenomenon also shows how these factors work satisfaction that consist of Compensation, Employment, Direct supervisor or manager, program promotion, and coworkers are interrelated and can influence the formation of employee commitment to the organization.

\section{Literature Review}

Organizational commitment is defined as the relative strength of individual identifying himself into the part of the organization 's involvement, which is characterized by the acceptance of the values and goals of the organization, seeking the organization's willingness and desire of maintaining membership in an organization. Wangsadjaja (2006) distinguishes commitment to the organization of three components, namely Affective Commitment, Normative Commitment, and continuance commitment.

- Affective Commitment is associated with emotional commitment, identification and involvement of employees in the organization. Employees with high Affective components, do not break away from the organization because keinginnya to remain bound to the organization. This commitment is the key to employees stay Because they want to.

- Normative Commitment. Have term employees stay Because they have to, an employee beliefs about the obligation to contribute to the organization. Employees must carry out its work to achieve the goals set by the company.

- Continuance commitment is a commitment that is formed on the basis of rational cost-benefit considerations faced by employees when faced with the decision to come on board in the organization or about to come out of the organization. (employees stay Because they feel they ought to).

Influence of Organizational Commitment: Conditions to be faced by the organization when employees have low commitment as follows:

- High levels of abseentism. (high levels of absenteeism)

- High levels of turnover (employee turnover rate is high). This relates to the costs incurred by the company to recruit and train new employees.

- unwillingness to share and make-sacrifice. Unwillingness to share and sacrifice for the benefit of the organization. Employees who have a low commitment end low motivation and result in decreased productivity.

\section{$\bullet$}

An organization that sees its employees and applies as a family member organizations, will be an overwhelming urge to increase organizational commitment. In turn, organizational commitment are high will result in a wide range of attitudes and positive behavior, such as avoiding actions, behaviors and attitudes that harm the good name of the organization, loyalty to the leader, the peer level and to subordinates, high productivity, willingness to resolve conflicts through consultation and etc.

Job Satisfaction: Job satisfaction is one's attitude towards her work (Sariyathi, 2003) . Someone who works a high level of satisfaction will have a positive attitude towards work. Conversely, if a person is not satisfied with his work will have a negative attitude towards work. Siagian (1999) argued that job satisfaction is the attitude and feelings towards their work, the employment situation and working conditions in the work environment that is the result of the assessment is subjective. Job satisfaction is closely related to the emotional state of pleasant and unpleasant from the perspective of employees on the job. The management must constantly monitor job satisfaction because it affects absenteeism, labor turnover, complaints, and other personnel issues (Handoko, 2001). To discuss job satisfaction several theories have been proposed to state why someone enjoys his job so that the commitment can be created, and beneficial to both parties, both the employees and the company itself.

- Comparison of Interpersonal Theory (Interpersonal Comparison Theory), also known as Discrepancy Theory. According to the discrepancy theory advanced by Porter (1961), job satisfaction or dissatisfaction felt by individuals is the result of a comparison made by himself against a variety of things that are easy to obtain from his job and he hopes . 
- The theory expressed by Frederick Herzberg called two-factor theory (Two Factor Theory). Satisfaction Factors are factors or circumstances that are formed as a source of job satisfaction which, if not met will cause dissatisfaction and work motivation. Disatisfaction (Hygiene Factors) are factors that become evident source of dissatisfaction which consists of income, supervision, personal relationships, working conditions, and status .

- Equity Theory ( Theory of Justice ). According Sariyathi (2003) which states that a person will experience satisfaction or dissatisfaction with the work depends on whether he felt the justice or injustice of the situation. Each employee will compare the inputs - outcomes ratio with the inputs outcomes himself another employee (comparison person)

- Theory Fulfillment (Need Fulfillment Theory). According to this theory, employee job satisfaction depends on whether or not the employees' needs are met. Theory of needs by Maslow hierarchy of human needs is 1 ). physiological needs, 2 ). Security needs, 3 ) the need for a sense of belonging, to be accepted by the group, afilisi, interaction, 4 ) . The need for self-esteem, 5 ) . The need for selfactualization use abilities, skills, and potential.

According Wangsadjaja (2006) job satisfaction consists of five indicators, namely:

- Compensation, such as salaries. Employees want dipresepsikan as fair compensation system, no doubt, and in line with her hope. When salaries are seen as fair based on the demands of work, skill level of the individual and the community wage standards are likely to be generated satisfaction.

- The work itself. Employees tend to prefer jobs that provide opportunities to use abilities and skills, freedom, and feedback menganai job. Less challenging job of creating saturation, but too much of a challenge can also create frustration and feelings of failure.

- Direct Supervisors or supervision have an important role in management. Supervision relating to the employee in performing his job. Employees generally prefer to have supervision that is fair, open, and work with subordinates.

- Promotion of work. Promotion occurs when an employee moves from one job to the higher positions, with responsibilities and organizational level. At the time of promoted employees generally face increasing demands and skill, ability, and responsibility. Most employees feel positive because it promoted.

- Co-workers. For most employees, the work also fills the need for social interaction. Therefore, not surprisingly, have friendly colleagues and support will lead to increased job satisfaction.

\section{Conceptual Framework}

For ease of understanding, it can be made frame of the study as follows:

\section{Figure 1: Conceptual Framework Research}

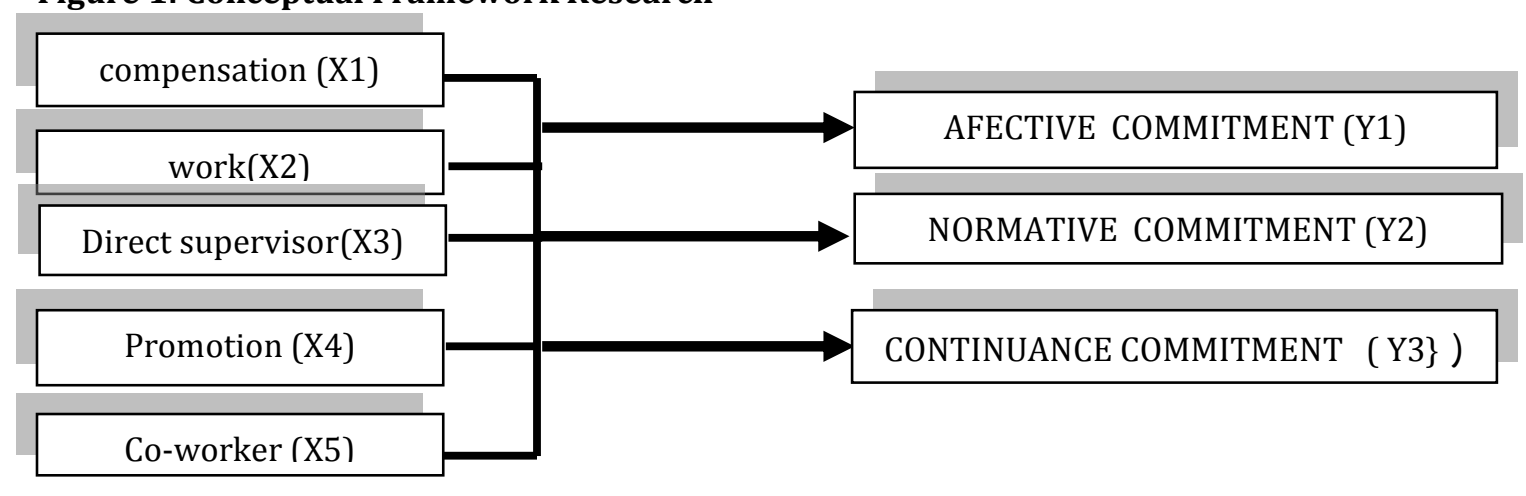

\section{Methodology}

This type of research used in this research is Quantitative Descriptive Analysis. This research was conducted at PT ( Persero ) Angkasa Pura I Branch Hasanuddin International Airport in Makassar. The sample used some 70 people who were at 3 dvisi namely: 
1. Division of Commercial and Business Development $=21.2$. Finance Division $=20.3$. Division of Personnel and General $=29$.

In consideration, the employee at the 4 other divisions of the Division of Air Traffic Operations, Airport Operations Division, Division of General Engineering and Equipment, and Electronic and Electrical Engineering Division has a level of intensity of the work is very high. Data collection tool that is used in the form of aquestionnaire about job satisfaction and employee commitment to the organization. Until the time limit data collection in the form of a questionnaire, the total number of questionnaires returned by 65 respondents. The number of samples is the basis for the next stage of data processing. This Analysis is used Multiple linear regression is formulated as follows:

$\mathrm{Y}=\mathrm{b} 0+\mathrm{b} 1 \mathrm{x} 1+\mathrm{b} 2 \mathrm{X} 2+\mathrm{b} 3 \mathrm{X} 3+\mathrm{b} 4 \mathrm{X} 4+\mathrm{b} 5 \mathrm{X} 5+\mathrm{e}$

Where:

$\mathrm{Y}=$ Commitment to the organization

b0 $=$ Constant

$\mathrm{X} 1$ = Compensation

$\mathrm{X} 2=$ Work

$\mathrm{X} 3$ = Supervisor

$\mathrm{X} 4$ = Promotion

$\mathrm{X} 5$ = Coworkers

b1 , b2 , b3 , b4 , b5 = Regression Coefficients

$\mathrm{e}=$ Variable bully

The variables used in this study include:

1. The independent variable, the variable suspected as the cause of the dependent variable. In this case the independent variable is the job satisfaction of employees consisting of: Compensation ( X1), Employment ( X2 ), Supervisor ( X3 ), Promotion ( X4 ), and Coworkers ( X5 ). 2. The dependent variable, the variable that allegedly occurred as a result of the interaction of independent variables. The dependent variable in this study is Commitment ( $\mathrm{Y}$ ) to the organization.

\section{Results and Discussion}

Test the validity of using the technique of product moment correlation $r$ significance level 0:01 correlate with scores of each item statement with a total score variable. The validity of the test results above shows all variables in the study questionnaire declared invalid. Measurement reliability using Cronbach alpha ( $\alpha$ ). If the coefficient Cronbach alpha $(\alpha)$ value is greater than the minimum reliability, namely 0.06 , then each item in the questionnaire statement acceptable or reliable. The reliability of the entire instrument measurement results showed Cronbach alpha coefficient $(\alpha)$ is worth 0.902 which means that the whole point statement can be accepted. Multikolinearitas detection can be done through VIF. If the value is greater than five VIF (VIF $>5$ ), it is estimated to occur multikolinear, but if the value is smaller VIF 5 ( VIF $<5$ ), it is not expected to occur multikolinear.

Table 1: Test Results Multicolinearity

\begin{tabular}{lcc}
\hline No Variable & VIF & Description \\
\hline 1 Compensation (X1 ) & 1,395 & Not happening Multicolinearity \\
2 Work ( X2 ) & 1,216 & Not happening Multicolinearity \\
3 Direct Supervisors ( X3 ) & 1,453 & Not happening Multicolinearity \\
4 Promotion (X4) & 1,211 & Not happening Multicolinearity \\
5 Partners (X5) & 1,559 & Not happening Multicolinearity \\
\hline
\end{tabular}

Source : Primary data are processed , 2010

The analysis showed the highest VIF 1.559 where the value is less than five $(1.559<5)$ it can be said not occur multikolinear the independent variable.

Results Descriptive Analysis Level of Satisfaction and Organizational Commitment Level: The average value ( mean) of the variables of job satisfaction and commitment as follows :

- Mean variable compensation (X1) = 3.7462 
- Mean Job variables (X2) $=3.9346$

- Mean Direct Supervisors variable (X3 ) $=3.9923$

- Mean Promotions variable (X4) $=3.7923$

- Mean Partners variable (X5) $=3.9808$

- Mean Organizational Commitment variable $(Y)=3.9374$

Table 2: Regression Test Results

\begin{tabular}{|c|c|c|c|}
\hline No Variable & unstandardized Coefficients & t-test & $P$-Value signification \\
\hline 1 ( Constant) & $\begin{array}{ll}-0.025 & 0 .\end{array}$ & & -0.040 \\
\hline 2 Compensation ( X1) & 0.256 & & 0.004 \\
\hline 3 Work ( X2) & 0.124 & & 0.346 \\
\hline 4 Direct Supervisors (X3) & 0.017 & & 0.865 \\
\hline 5 Promotion ( X4) & 0.278 & & 0.002 \\
\hline 6 Partners ( X5 ) & 0.350 & & 0.011 \\
\hline $\begin{array}{l}\mathrm{R} 2=0.536 \\
\text { significance on } \mathrm{P}<0 .\end{array}$ & $\mathrm{R}=0.732$ F-count & 3.627 & Sig $F=0000$ \\
\hline
\end{tabular}

Source : Primary data are processed 2010

The data above, it can be described that the level of employee satisfaction on every job satisfaction is high variable. This is indicated by the value range of each variable job satisfaction between 3:40<4.20. Similarly, a picture of the high level of commitment to the organization demonstrate the value of 3.9374, which means the level of employee commitment PAP-I is high. Based on the above data, the correlation coefficient ( $r$ ) indicates the value of 0732 which is between the range of values from 0.26 to 0.75 . It means that there is a strong relationship amounted to $73.2 \%$ between the variables of job satisfaction which consists of compensation (X1), work ( X2), the direct supervisor ( X3 ), promotion ( X4) and coworkers (X5) of the Commitments ( $\mathrm{Y}$ ) on the company .

The value of $F=13.627$ with significant value $F$ change $(p)=0.000$ is smaller when compared to $0: 05$. This means that the independent variables consisting of compensation ( X1), work ( X2), the direct supervisor ( $\mathrm{X} 3$ ), promotion ( X4) and coworkers ( X5 ) simultaneously positive and significant effect on the dependent variable, namely Commitment ( Y ) employees PT ( Persero ) Angkasa Pura I Branch Hasanuddin International Airport in Makassar. The coefficient of determination ( R2 ) indicates the value of 0.536, this means that the independent variables consisting of Compensation ( X1 ), Employment ( X2 ), Direct Supervisors ( X3 ), Promotion ( X4), and Coworkers ( X5) are included in the model is able to explains the diversity of the dependent variable, namely commitment $(\mathrm{Y}) 53.6 \%$, while $46.4 \%$ is explained by other variables not included in the regression model. These variables comprise corporate policy, communications, performance, supervision, facilities and infrastructure, as well as motivation.

The regression equation is formulated as follows:

$Y=-0,025+0,256 X_{1}+0,124 X_{2}+0,017 X_{3}+0,278 X_{4}+0,350 X_{5}$

B0 coefficient $=-0.025$, meaning that if the variable compensation (X1), work (X2), the direct supervisor (X3), promotion (X4), and co-workers (X5) no change increase, the organizational commitment (Y) will decrease by $2.5 \%$. Coefficient B1 $=0.256$ means that any increase in variable compensation (X1) of the unit it is expected to increase by $25.6 \%$ commitment. $\mathrm{T}$ value of 3.015 with a significance level of $0.004(\mathrm{sig}<0.05)$ means that there is a positive and significant influence between compensation (X1) with the commitment (Y), assuming other variables $(\mathrm{X} 2, \mathrm{X} 3, \mathrm{X} 4$ and $\mathrm{X} 5)$ constant. $\mathrm{B} 2=$ coefficient of 0.124 means that any increase in employment variable (X2) of the unit, it is expected to increase by $12.4 \%$ commitment. T value of 0.950 with a significance level of 0.346 (sig> 0.05) means that there is no significant influence between work (X2) with commitment $(\mathrm{Y})$, assuming other variables $(\mathrm{X} 1, \mathrm{X} 3, \mathrm{X} 4$ and $\mathrm{X} 5)$ constant. Coefficient $\mathrm{b} 3=0.017$ means that any increase in variable direct supervisor (X3) of the unit, it is expected to increase the commitment of $1.7 \%$. T value of 0.171 with a significance level of 0.865 (sig> 0.05) means that there is no significant influence between the direct supervisor (X3) with commitment $(\mathrm{Y})$, assuming other variables (X1, X2, X4 and X5) constant. $\mathrm{B} 4$ coefficient $=$ 0.278 means that any increase promotion variable (X4) of the unit, it is expected to increase by $27.8 \%$ commitment. T value of 3.307 with a significance level of $0.002(\operatorname{sig}<0.05)$ means that there is significant 
influence between promotion (X4) with commitment $(\mathrm{Y})$, assuming other variables (X1, X2, X3, and X5) constant. B5 coefficient $=0.350$ means that any increase in variable coworkers (X5) one unit, it is expected to increase by $35 \%$ commitment. T value of 2.617 with a significance level of $0.011(\mathrm{sig}<0.05)$ means that there is significant influence between coworkers (X5) with commitment $(\mathrm{Y})$, assuming other variables $(\mathrm{X} 1, \mathrm{X} 2, \mathrm{X} 3$, and X4) constant. Based on the description above, it can be seen that there are three independent variables consisting of Compensation ( X1 ), Promotion ( X4 ), and Coworkers (X5) are positive and significant effect on the dependent variable is Organizational Commitment (Y). While the Employment ( X2 ) and Direct Supervisors ( X3 ) had no significant effect on organizational commitment PAP -I Branch Hasanuddin International Airport.

Employee satisfaction simultaneously positive and significant impact on the organization's commitment to the PAP-I Hasanuddin International Airport in Makassar. Results of the assessment of the respondents also describe the level of employee satisfaction and organizational commitment levels at PT (Persero) Angkasa Pura I Branch Hasanuddin International Airport in Makassar is high. Compensation system according to the workload, responsibilities, trends comparison of compensation received by the received others, and timeliness of payment has been providing job satisfaction for employees PAP-I. This opinion is supported by the statement Flippo (2008) that the compensation is remuneration that is fair and reasonable given to workers of his services in achieving organizational goals. Patton (1977) in Rosary (2003) also suggests 7 compensation policy criteria that should be considered by any company that is 1) Adequate, 2). Worthy, worthy, reasonable and fair, 3). Balanced and fit, 4) The ability of companies, 5). Can meet the basic needs of employees, 6). As a motivator, and 7). Can be received by an employee. Partial regression results show that the variable compensation and significant positive effect on organizational commitment. If the compensation received by employees in accordance with the criteria and principles, then formed the confidence of employees in the achievement of organizational goals that synergy with the personal goals of employees, involvement in activities, and loyalty to the organization. Previous research conducted by Djati (2003) suggested that job satisfaction of employees in compensation has a significant influence on loyalty, willingness to work and pride of employees in the organization. Ironically, the results of current research and the results of previous research on compensation, contrary to the reality of what happened in the PAP-I. Employee dissatisfaction that led to strike action in May 2008 originated from the demands of employees to increase welfare. As a state-owned company they want the salaries of its own based on professionalism, because until now the standard implementation of the salary is based on the standard salary of civil servants in 2006.

Theory of justice that support employee dissatisfaction situation of PAP-I expressed by Sariyathi (2003) that a person will experience satisfaction or dissatisfaction with the work depends on whether he felt the justice or injustice of the situation. Each employee will compare the inputs-outcomes ratio with the inputs-outcomes himself another employee (comparison person). In other words, a person tends to compare the compensation or reward earned by the compensation received by others who have a similar workload. When the amount of compensation between the two people are the same, it would appear job satisfaction. When smaller then there will be a sense of disappointment which then reduces the motivation to work well. If one receives more, then he will be motivated more strongly. (Mangkunagara, 2008). Similarly, one of the instruments in the Theory of Hope (Expectancy Theory) by Vroom suggested that the concept of fairness in reward (The Equity of Reward), assume remuneration derived less than the input and returns achieved by others, it is considered unfair. The work has a positive influence but not significant in shaping the organizational commitment to the PAP-I Although the results of the assessment of the respondents showed the work carried out in accordance with the knowledge and expertise of each employee, there is a clear job description, the freedom of responsible decision-making, and job it does give a lot of lessons.

The theory put forward by Frederick Herzberg support the assessment of the respondents referred to as twofactor theory (Two Factor Theory). According to the characteristics of jobs that are grouped into two categories: disatisfaction or dissatisfaction and satisfaction or gratification. Factors disatisfaction are factors or circumstances that are formed as a source of job satisfaction which, if not met will not lead to satisfaction and motivation. Conversely, if fulfilled will lead to satisfaction and motivation. These factors include: achievement, ability, authority, responsibility, and promotion. The above theory is supported by research conducted by Adianto and Agustin (2005) discloses the effect of job characteristics and job satisfaction. 
According to them if the employee has characteristics corresponding to his job, then his performance and work satisfaction will increase. Research conducted by Perdanawati (2006) supports the results of the partial regsesi that said work had no significant effect on commitment. Only variable salary, supervisors, and coworkers who have a significant effect on organizational commitment. Basically the work within the scope of the PAP-I has been structured and standardized, so that employees have to finish it responsibly. In contrast to private companies that prefer the profitalisme, the work carried out is challenging, use initiative, abilities, and skills. Employees prefer jobs that match the skill, liberty and the feedback from his job, but if too much of a challenge can lead to frustration and feelings of failure. Partial regression results also illustrate the variable direct supervisor and not significant positive effect on organizational commitment. Yet according to the respondents their superiors always guiding, directing, to discuss issues related to the work, inform the change company policies, and motivating career development. Actually, standardization leadership set by the company in general has led the process as proposed by Winardi (2007).

According to the process of leading a direct supervisor is 1). Make decisions, 2). Focusing on objectives to be achieved, 3). Planning and formulating policies, 4) Organize and place employees in positions that exist, 5). Carry out communication with subordinates, colleagues and their superiors, 6). Lead and supervise, and 7). The leaders supervise the activities. Standardization permanent boss or leader this is not too influential to employees to establish a commitment to the organization. If studied further, the role and process of a direct supervisor can have an impact as a motivator in improving labor productivity. Information about career development or promotion of employees in the company is always available and promotional programs provided by the company was considered quite meet the principles of fairness and objectivity. Personal benefits felt by employees through this program is the emergence of personal pride, of high social status and income increase. Besides the promotion program gives a positive stimulus to boost employee productivity. This result is also supported by a statement Hasibuan (2005) who said promotion of employees have an impact on the increase in social status, authority, responsibility, and income for employees. Regression results show promotion variables have a significant influence on the formation of the organization's commitment to the PAP-I. Previous studies by Hutagalung (2008) also revealed that the promotion and compensation significant effect on organizational commitment.

Unity work in team work can improve employee job satisfaction. Theory group's view (Social Reference Group Theory) reveals employee satisfaction is not dependent on the fulfillment of the needs, but relied heavily on the views and opinions of which the employee is considered as the reference group. Share information, conduct discussions to solve the problem is an active activity among fellow colleagues in this company. These results are based on an assessment of respondents view when associating with theory states that the group of employees will be satisfied if the results of its work in accordance with the interests and needs that are expected by the working group. On the other hand, informal relationships between colleagues constantly intertwined like a hobby or exercise together, recitation or religious activity, and recreation. This solid interaction will foster a sense of community in realizing the achievement of organizational objectives. This is evident from the results that showed variable regression coworkers indeed significantly influence the formation of organizational commitment. The regression results give a picture of the relationship between the variables of job satisfaction showed a strong correlation and impact on organizational commitment.

Employees who have a basic affective organizational commitment to have different behavior with employees based continuance. Employees who want to become members would have a desire to use the business in accordance with the objectives of the organization. Instead, they were forced to become a member would avoid financial losses and other losses, so it might just do the job that is not optimal. Meanwhile, normative commitment that developed as a result of the socialization experience, depending on the extent to which employees have a feeling of obligation. The results of research on the influence of job satisfaction on the commitments proposed by Wangsadjaja (2006) also suggests that employees have a high level of Affective Commitment, Normative Commitment while, and continuance commitment at a sufficient level. Similarly, the level of job satisfaction show a high level. If the company does not attempt to make changes to increase job satisfaction factors, the impact on the employees' commitment to the organization. Changes made not only on the variable salary, job, direct supervisor, promotion, and co-workers, but for all dimensions that can be used as indicators of job satisfaction as policies that can improve the compensation system kesejahretaan employees. It is feared occurred during a strike in five airports under the PAP-I. According to Wangsadjaja 
(2006) This action is still within reasonable limits as Voice expression in the PAP-I. Although the internal action occurs in the PAP-I, but they remain committed to enhancing flight navigation services to the public in accordance with the purpose, vision, and mission.

\section{Conclusion and Recommendations}

Results of research and discussion that has been described, it can be concluded as follows:

- The description of the level of employee satisfaction and organizational commitment at PT (Persero) Angkasa Pura I Branch Hasanuddin International Airport in Makassar is high.

- There is a strong relationship between the variables of job satisfaction) consisting of compensation, employment, direct supervisor, promotion, and co-workers on employee job satisfaction

- Overall there is a positive and significant influence between the factors of employee satisfaction which consists of Compensation, Employment, Tops Direct, Promotion, and Partners on organizational commitment at PT (Persero) Angkasa Pura I Branch Hasanuddin International Airport in Makassar. In partial compensation has a significant influence on organizational commitment. Work variables have a positive effect but not significant between work and organizational commitment. Variable Direct Supervisors also have a positive but not significant effect on organizational commitment. While variable promotion and co-workers and significant positive effect on organizational commitment.

- Limitations of this study is that the sample used was less representative where samples are taken only three divisions: Division of Commercial and Business Development, Financial Division, and the Division of Personnel and General. Another limitation is the questionnaires filled out by respondents was the uniformity of response.

\section{References}

Adianto, H. \& Agustin, Y. (2005). Analysis of Effect of Job Characteristics and Job Satisfaction on Job Performance. http://puslit.petra.ac.id/ puslit/journals/

Danan, M. H. (2008). Relation Job Satisfaction and Organizational Commitment with Organizational Citizenship Behavior (OCB) in Health Polytechnic Banjarmasin. http://lrc-kmpk.ugm.ac.id/

Djati, S. P. (2003). Assessment of Compensation Satisfaction on Organizational Commitment. http://puslit.petra.ac.id/ puslit/journals/

Flippo, E. B. (2008). Personnel Management. Interpreting Moh. Masud. Sixth edition. Erland, Jakarta.

Handoko, T. H. (2001). Personnel Management and Human Resources. BPFE, Yogyakarta.

Hasibuan, M. S. P. (2005). Human Resource Management. Revised Edition, Bumi Karsa, Jakarta.

Hutagalung, P. S. (2008). Compensation and Promotion Effect Analysis on Job Satisfaction Employee at PT. Asuransi Dharma Bangsa. http://puslit.petra.ac.id/ puslit/journals/

Joseph, D., Kok-Yee, N., Koh, C. \& Soon, A. (2007). Turnover of information technology professionals: a narrative review, meta-analytic structural equation modeling, and model development. MIS Quarterly, 31(3), 547-577.

Mangkunagara, A. A. A. K. (2008). Human Resources Management Company. PT. Teens Rosdakarya, Bandung.

Perdanawati, S. (2006). Effect of Job satisfaction Employee Commitment against Cleaning Service CV Duta Karya Bersama Hospital "X" Surabaya.

Porter, L. (1961). A study of perceived need satisfactions in bottom and middle management jobs. Journal of Applied Psychology, 45(1), 1-10.

Rosary, R. (2003). Establishing Compensation Plan. http://lrc-kmpk.ugm.ac.id/

Sariyathi, N. K. (2003). Employee Performance (A Study of Theory). Accredited Journal No.34 / Dikti / Kep / 2003. (Online), (accessed 9 April 2008).

Siagian, P. S. (1999). Human Resource Management. Earth Literacy, Jakarta.

Sopiah. (2008). Perilaku Organisasi, Andi, Yogyakarta.

Sugiyono. (2006). Methods of Research Administration. Mold fourteenth. CV.Alfabeta. Jakarta.

Wangsadjaja, C. (2006). Job Satisfaction of the Commitment. http://puslit.petra.ac.id/ puslit/journals/

Winardi, J. (2007). Management of Organizational Behavior. Revised Edition. Kencana, Jakarta. 